\title{
ASPECTE BIOTEHNOLOGICE DE ÎNMULȚIRE A ARONIEI Melanocarpa (MICHX.) ELLIOTT PRIN VITROCULTURI
}

\author{
Ciorchină Nina ${ }^{1}$, Calalb Tatiana ${ }^{2}$, Onica Elizaveta ${ }^{1}$ \\ ${ }^{1}$ Grădina Botanică Națională (Institut) „,Alexandru Ciubotaru”, Chișinău, Republica Moldova \\ ${ }^{2}$ Universitatea de Stat de Medicină și Farmacie „,Nicolae Testemițanu”, Chișinău, Republica Moldova \\ e-mail: ninaciorchina@mail.ru, tatiana.calalb@usmf.md
}

Scorușul negru Aronia melanocarpa (Michx.) Elliott aparține familiei Rosaceae, genul Aronia, nativă din estul Americii de Nord. Planta prezintă un arbust multianual cu numeroase ramuri, de la 10-15 per planta tânără, și circa la 50-60 lăstari la plantele mature, cu o înălţime între 1,5-3,0 m, iar fructele au diametrul de 10-12 mm. Fructele proaspete sunt sursă bogată de antociani, substanțe tanante, vitaminele C, E, acizi organici, microelemente, carotenoide, zaharuri, etc. Fructele de aronia conţin de 15 ori mai mulți antioxidanţi decât afinele. Pentru producția de fructe, soiul cel mai productiv este soiul Nero.

Aronia, face parte dintre culturile arbuștilor fructiferi din R. Moldova care aduc profituri mari fiind cultivate pe suprafețe mici. Fructele mici și negre sunt solicitate, astfel plantaţiile în R. Moldova au demarat în extindere. Amelioratorii și cercetătorii sunt orientaţi pentru selectarea și obținerea soiurilor de aronie cu proprietăţi decorative și fructe de înaltă calitate și productivitate sporită. Aronia tradițional se înmulțește prin butași, dar această metodă are o rată de prindere mică, de 5 la sută. O altă variantă este înmulțirea generativă prin semințe. Pentru aceasta un fermier are de așteptat 2-3 ani, totodată materialul săditor (puieții) obținuți sunt neomogeni, neuniformi. O metodă de înmulțire rentabilă pentru aronie este cultura in vitro.

În Grădina Botanică Națională (Institut) „Alexandru Ciubotaru” (GBNI), lab. de Embriologie și Biotehnologie se cercetează 2 soiuri de aronie: Nero și Alexandrina. Soiul Alexandrina, este un soi creat de un grup de cercetători din GBNI (Palancean A., Roșca I., Onica E.), soiul Nero, este soi înregistrat în catalogul de plante a R. Moldova. Pentru a obține material iniţial, meristemele lăstarilor au fost prelevate din colecția GBNI. În urma cercetărilor efectuate asupra soiurilor de aronia pentru inocularea plantelor în cultura in vitro se recomandă prelevarea fragmentelor de lăstari vegetativi apicali și laterali în perioada de creștere intensă a țesuturilor. Meristemele inoculate pe medii nutritive au supraviețuit și au dat naștere vitroculturilor la 88,9\%.

Pentru microclonarea vitroplantulelor obținute au fost testate mediile de cultură suplinite cu BAP (1,0 mg/l) și 2ip (10 mg/l). Pe aceste medii nutritive timp de 60 zile, se măreşte considerabil inducerea mugurilor laterali pe partea bazală a axului plantulei, ceea ce favorizează o lăstărire multiplă care mai apoi serveşte drept sursă de material biologic pentru micropropagare şi sporirea masei vegetale. Pe mediul cu 2ip se formează în jur de 12,0 lăstari în eprubete la soiul Alexandrina, cu o lungime a lăstarilor de 8 cm, iar pe mediul cu BAP, formează în jur de 5,0 lăstari per inoculi. La soiul Nero procesul de microclonare este mai anevoios, rata de formare a microclonilor este mai diminuată, per explant se formează circa 5 microcloni, pe mediul suplinit cu 2ip și 2-3 microcloni pe mediul suplinit cu BAP în concentrație de $1,0 \mathrm{mg} / 1 \mathrm{cu}$ o lungime a microclonilor de maxim $3 \mathrm{~cm}$. Microclonii obținuti sunt butășiți în dimensiuni de 2,5 cm sunt pasaţi pe medii nutritive de bază MS, modificat, lichid (AIA 0,2 mg/l, zahăr alimentar $30 \mathrm{~g} / \mathrm{l}$ ). Pe acest mediul în perioada de 30 zile butașii soiului Alexandrina cresc de 10-12 cm, formează sistem radicular, butașii soiului Nerro, formează sisitem radicular, însă lungimea lăstarului nu depășește $4 \mathrm{~cm}$. Plantulele obținute in vitro sunt trecute la condiții ex vitro pentru aclimatizate. Compoziția substratului: sol de gazon, turbă, nisip, pierlit în raport de 2:1:1:1. 